\title{
Catasetum $x$ fausti Bicalho - Orquidaceae, um novo híbrido natural
}

\author{
HAMILTON DIAS BICALHO ${ }^{1}$
}

${ }^{1}$ Departamento de Horticultura, ESALQ, USP. Av. Pádua Dias, 11. CEP 13418-900, Piracicaba (SP).

\begin{abstract}
É sempre oportuno relembrar a importância dos híbridos naturais para os taxionomistas, sejam eles botânicos ou da zoologia. Pressupõe a união de duas espécies diferentes e a óbvia troca de genes, fenômeno realizado por insetos sociais especializados que, no final da pesquisa, nos proporciona mais conhecimento sobre barreiras geográficas e, no caso do gênero Catasetum, a real importância da flor feminina.
\end{abstract}

No caso presente, a espécie em questão, salvo maior juízo, é o produto natural do cruzamento do Ctsm. longifolium com o Ctsm. saccatum. No exemplar que examinamos, alguns atributos podem ser notados principalmente aqueles relacionados com a arquitetura da planta e no tocante à morfologia da flor. Os "pseudobulbos" são relativamente grossos e compridos, portanto folhas finas e estreitas como em Ctsm. longifolium. A flor lembra o Ctsm. saccatum com as sépalas marrom claras lanceoladas, a dorsal $28 \times 9 \mathrm{~mm}$ e a lateral, 31 × $8 \mathrm{~mm}$; pétalas também lanceoladas, mais largas, verde limão, claras, $28 \times 14 \mathrm{~mm}$; labelo em corte longitudinal idêntico ao Ctsm. saccatum mostrando profundidade saquiforme $15 \times 15 \mathrm{~mm}$; parte superior quando explanada, de âmbito triangu- lar, com lobos laterais fimbrilhados e terminal acuminado, no total $36 \times 24 \mathrm{~mm}$; coluna amarelo clara, com antenas pouco desenvolvidas, em forma de gancho e atingindo, em comprimento, os bordos da profundidade saquiforme do labelo; inflorescência muito comprida, pendente, com inúmeras flores, mais de vinte no exemplar examinado, distribuídas por todo o eixo floral.

\section{Catasetum x fausti Bicalho hibr. nat. nov.}

Plantae aspectus referens Catasetum longifolium, pseudobulbis fusiformibus, plus minusve crassis, foliis gracilibus et longis; floribus referentibus Catasetum saccatum flores, labello expanso ostendente formam triangularem, oris lateralibus fimbriatis, apice acuto; columnae antennis unci instar attingentibusque sacco similes profundidatis labelli oras; inflorescencia longa, pendenti, pluribus floribus ornata, dispositis per totam ipsius longitudinem.

Tipo: BRASIL, Estado de Mato Grosso do Sul, Costa Rica, perto do rio Aporé, cultivado por Sr. Durval Ferreira. Holotypus SP 258301. 
Obs. O nome da espécie é homenagem do autor ao Sr. Fausto Cheida, orquidófilo de Assis, SP, pelos relevantes serviços prestados à orquidofilia nacional.

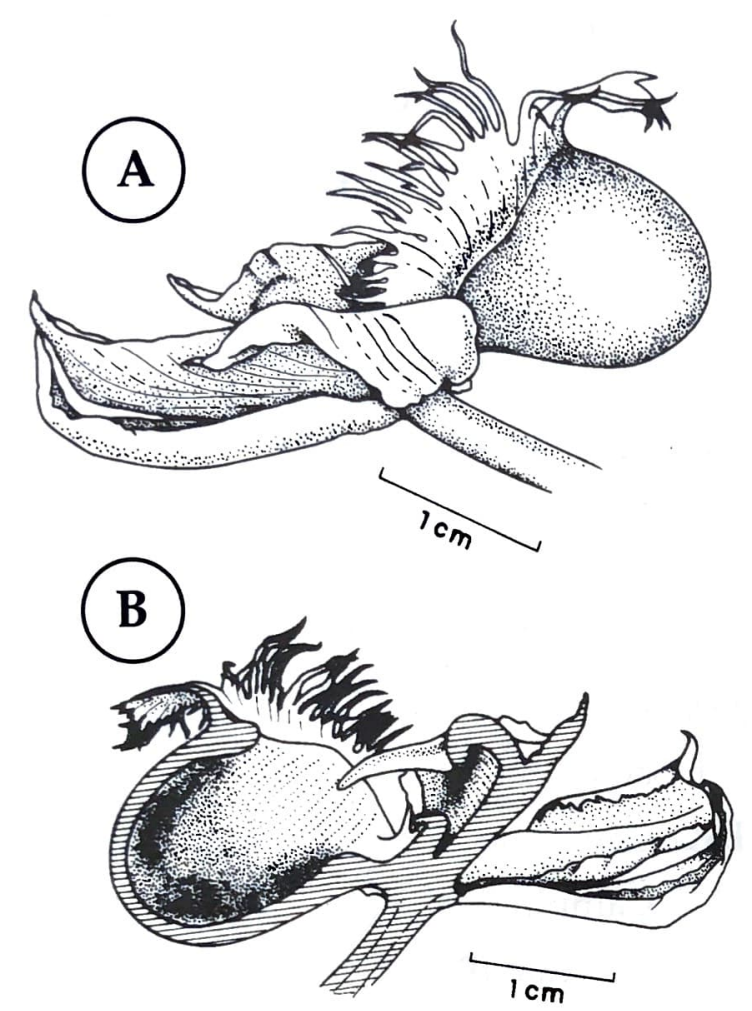

\section{Agradecimento}

$\mathrm{O}$ autor agradece os préstimos do $\mathrm{Pe}$. José González Raposo, C. M. F. pela versão latina.

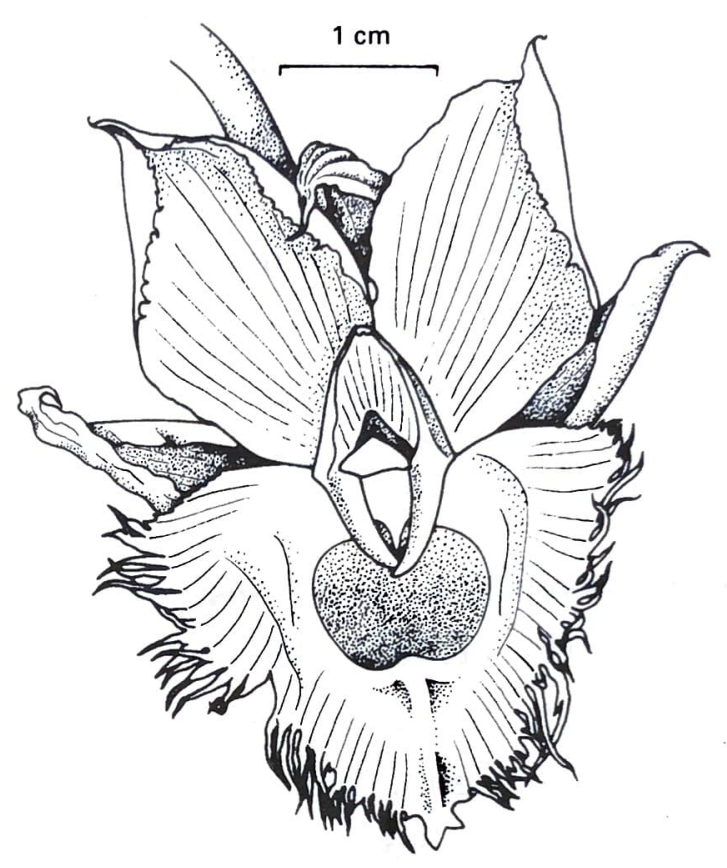

Figura 1. Perfil externo (A), perfil interno (B) e vista de cima, para mostrar as antenas e o âmbito do labelo (C) de Catasetum $x$ fausti Bicalho.

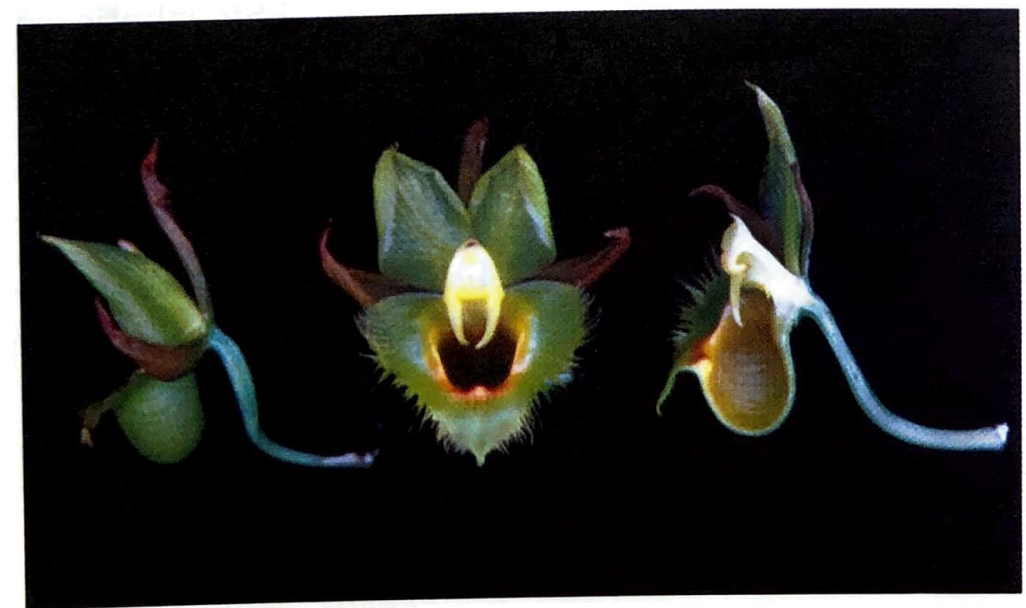

Figura 2. Perfil externo, flor vista de cima e perfil interno, respectivamente, de Catasetum $x$ fausti Bicalho. 